\title{
Knowledge mapping analysis of Ebola research
}

\author{
Zhao XY ${ }^{1}$, Sheng $\mathrm{L}^{1}$, Diao $\mathrm{TX}^{1}$, Zhang $\mathrm{Y}^{1}$, Wang $\mathrm{L}^{1}$, Yanjun $\mathrm{Z}^{2}$ \\ Institute of Health Service and Medical Information, Beijing, China. diaotx@263.com
}

\begin{abstract}
OBJECTIVE: To reveal the overall situation of research on Ebola virus via visual knowledge mapping analyses of the literatures regarding Ebola virus all around the world, e.g., literature metrology and topic evolvement. METHODS: On the basis of the database Web of Knowledge (SCI), a knowledge graph was built by comprehensively utilizing software such as BIBEXCEL, GEPHI, VOSVIEWER, and HistCite.

RESULTS: According to the results of literature analysis, publications on Ebola virus boomed in 2014, and the research focus transferred gradually from basic research (viral glycoprotein) in 1999 to the prevention and treatment research (vaccine). The United States are in a dominant position in the field of Ebola virus research, wherein the US army (United States Army Medical Research Institute of Infectious Diseases) has the strongest research capacity.

DISCUSSION: Ebola virus is an important potential biological warfare agent, and some researches may not be published in the form of literature. So the result of literature metrology can only partially reflect the situation of Ebola virus research. In addition, close attention should be paid to the biosafety risk of Ebola research (Tab. 5, Fig. 5, Ref. 14). Text in PDF www.elis.sk.

KEY WORDS: Ebola, visualization, bibliometrics.
\end{abstract}

\section{Introduction}

The outbreak of the Ebola hemorrhagic fever (EHF) in February 2014 in West Africa is the worst Ebola epidemic in the history, and is one of the most serious public health crises which the mankind has ever encountered in the 21st century. EHF is an acute hemorrhagic disease caused by Ebola virus (EBOV), and it is classified as one of the most dangerous viruses by WHO as there are still no effective antiviral drugs and vaccines for EBOV9 (1). In this research, the Web of Knowledge (SCI) of Institute for Scientific Information of USA is used as the source of core data, with which the global research status and tendency of the Ebola virus are analyzed in order to provide data support and research ideas for the researchers who are occupied in the research of Ebola virus (2).

\section{Research method and data sources}

On December 16th, 2014, based on the platform of Web of knowledge (SCI) of Institute for Scientific Information of the USA, the keyword "ebola” was searched in the time range of 1986-2014, and 1335 related articles are retrieved. The full records including the references were downloaded and analyzed with the BIBEX-

${ }^{1}$ Institute of Health Service and Medical Information, Beijing, China, and ${ }^{2}$ Beijing University of Technology, Biomedical Engineering Center, Beijing, China

Address for correspondence: D. Tianxi, Institute of Health Service and Medical Information, Beijing, China.

Phone: +010.66931118
CEL software. The knowledge graph was built with the software GEPHI, VOSVIEWER and HistCite to show the main research institutes, authors and hotspots in the research field of Ebola virus in the world (3).

\section{Research results}

\section{Overall situation of Ebola virus research}

From 1995 to 2013, the quantity of worldwide literatures regarding Ebola virus is relatively stable and small (Fig. 1). The rising and falling on the curve of literature quantity is basically consistent with the curve of outbreak time of Ebola epidemics within the recent 20 years. In 2014, the quantity of the published articles increased sharply to 353 , which is in close relation to the outbreak of the largest and the most serious Ebola epidemic. The total citation frequency of the 1335 articles is 29440 , the selfcitation frequency within this field is 10919, the average citation frequency of each article is 22.02, and the h-index of this field is 88. The self-citation rate within the field is 0.37 (relatively low), which means that the development of the field is relatively mature, and there is a certain degree of intersection with other fields.

Distribution of Country and Region Involving Ebola Virus Research

The regions where a larger number of articles on Ebola virus are published is concentrated in the USA and Europe, and the USA is the global leader of this research field. In terms of the number of the published articles, the USA is at the top with the quantity of 665 , accounting for half of the total quantity of the published articles in the field worldwide. In terms of the quality, the average 

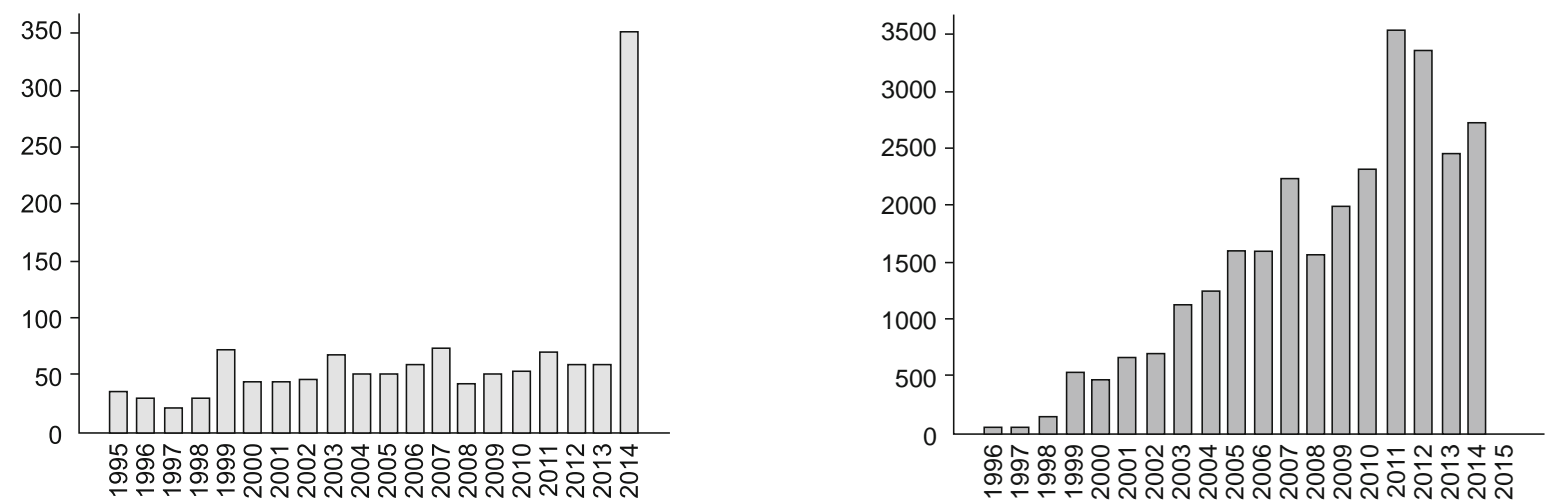

Fig. 1. The quantity of annually published articles in the field of Ebola virus research worldwide (left) and the citation frequency (right).

citation frequency of articles published in the USA is 33.95 and the h-index is 80, which are apparently higher than those of other countries. Moreover, Canada, Germany, France, Japan, the UK, Russia, Gabon, Belgium and Switzerland also have published a large quantity of articles regarding Ebola virus (Tab. 1).

\section{Comparison of the strength of Ebola virus research institutions}

Judging from the quantity and quality of the published articles, the US Army Medical Research Institute of Infectious Diseases (USAMRIID) is a giant in the field of Ebola virus research. This institute has published 165 articles in total in this field, with the average citation frequency of 48.78 and the h-index of 56, and

Tab. 1. Top 10 countries with the largest quantity of articles regarding Ebola virus.

\begin{tabular}{lcccc}
\hline Country & $\begin{array}{c}\text { Quantity of the } \\
\text { Published Articles }\end{array}$ & $\begin{array}{c}\text { Percentage } \\
(\%)\end{array}$ & $\begin{array}{c}\text { Average Citation } \\
\text { Frequency }\end{array}$ & h-index \\
\hline The USA & 665 & 48.99 & 33.95 & 80 \\
Canada & 118 & 8.826 & 25.84 & 32 \\
Germany & 115 & 8.601 & 41.62 & 37 \\
France & 92 & 6.881 & 37.49 & 31 \\
Japan & 87 & 6.507 & 24.78 & 25 \\
The UK & 62 & 4.637 & 12.31 & 10 \\
Russia & 39 & 2.917 & 15.62 & 11 \\
Gabon & 39 & 2.917 & 51.23 & 23 \\
Belgium & 38 & 2.842 & 19.87 & 15 \\
Switzerland & 38 & 2.842 & 23.58 & 13 \\
\hline
\end{tabular}

the quantity and quality of the published articles are significantly higher than other institutes. The other leading institutes include the Centers for Disease Control and Prevention in the USA (CTR DIS CONTROL PREVENT), National Institute of Allergy and Infectious Diseases of National Institutes of Health in the USA (NIAID, NIH), National Microbiology Laboratory of Public Health Agency of Canada (PUBL HLTH AGCY CANADA), University of Manitoba in Canada (UNIV MANITOBA), Philipps University of Marburg in Germany (UNIV MARBURG), the University of Tokyo in Japan (UNIV TOKYO), the University of Pennsylvania in the USA (UNIV PENN), the University of Wisconsin in the USA (UNIV WISCONSIN), and International Center for Medical Research of Franceville in Gabon (CTR INT RECH MED FRANCEVILLE) (Tab. 2). Through the analysis on the cooperation between the global institutions it was found that of the top 10 research institutions with the highest number of relevant articles, 6 are located in the core of the cooperation network, with high influence during cooperative processes. They are the US Army Medical Research Institute of Infectious Diseases, the Centers for Disease Control and Prevention in the USA, National Institute of Allergy and Infectious Diseases of National Institutes of Health in the USA, University of Manitoba in Canada, Philipps University of Marburg in Germany and the University of Tokyo in Japan (Tab. 2). The quantity of the published articles of the International Center for Medical Research of Franceville in Gabon ranks num-

Tab. 2. Top 10 institutions with the highest quantity of published articles regarding Ebola virus in the world.

\begin{tabular}{|c|c|c|c|c|}
\hline Name of Institution & $\begin{array}{c}\text { Quantity of } \\
\text { Published } \\
\text { Articles }\end{array}$ & $\begin{array}{l}\text { Total Citation } \\
\text { Frequency }\end{array}$ & $\begin{array}{c}\text { Average } \\
\text { Citation } \\
\text { Frequency }\end{array}$ & h-index \\
\hline US Army Medical Research Institute of Infectious Diseases (USAMRIID) & 165 & 8048 & 48.78 & 56 \\
\hline Centers for Disease Control and Prevention of the USA & 124 & 6093 & 49.14 & 47 \\
\hline $\begin{array}{l}\text { National Institute of Allergy and Infectious Diseases of the National Insti- } \\
\text { tutes of Health of the USA }\end{array}$ & 106 & 3010 & 28.4 & 30 \\
\hline National Microbiology Laboratory of Public Health Agency of Canada & 85 & 2209 & 25.99 & 27 \\
\hline University of Manitoba, Canada & 74 & 1910 & 25.81 & 24 \\
\hline Philipps University of Marburg, Germany & 67 & 3327 & 49.66 & 31 \\
\hline University of Tokyo, Japan & 65 & 1680 & 25.85 & 24 \\
\hline University of Pennsylvania, the USA & 52 & 2182 & 41.96 & 21 \\
\hline University of Wisconsin, the USA & 50 & 1960 & 39.20 & 24 \\
\hline International Center for Medical Research of Franceville in Gabon & 30 & 1540 & 54.73 & 18 \\
\hline
\end{tabular}




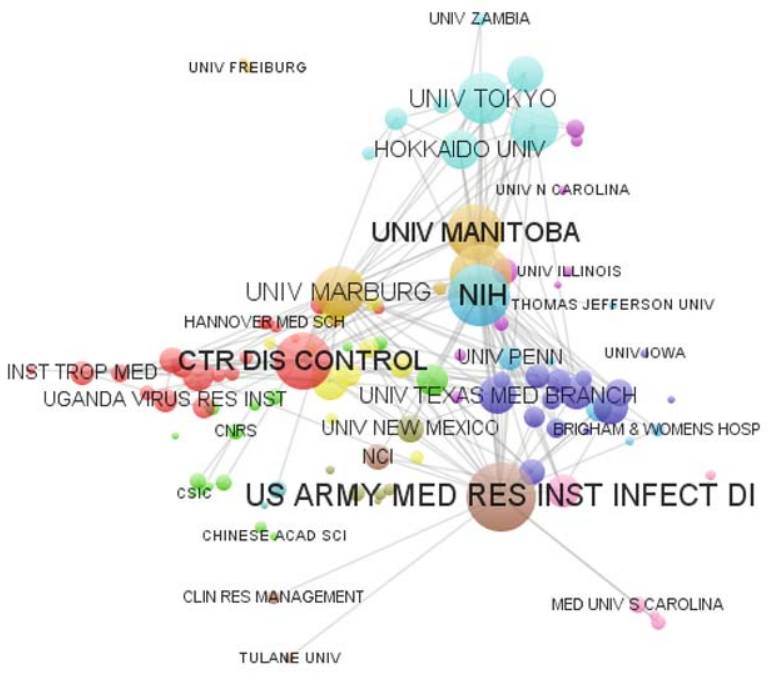

Fig. 2. Global cooperation network of the institutions in the field of ebola virus research.

ber 10, but its average citation frequency of the published article (54.73) is the highest. The reason may be that the research center received the Ebola patients directly during many outbreaks and can separate firstly the pathogenic viral strain. Most of these articles are published by cooperating with the research institutions of other countries including the USA, France, the UK, Germany, Switzerland, Thailand and South Africa (Fig. 2).

Distribution of core authors engaged in the research of Ebola virus

After data cleaning, the top 10 scientists (corresponding author) who published the largest number of articles in the field of Ebola virus research are ranked, wherein 9 scientists are employed in the institutions of the USA, including NIAID (under NIH), University of Texas, Centers for Disease Control and Prevention, University of Wisconsin and the USAMRIID. Only 1 scientist is employed in University of Marburg, Germany (Tab. 3). By analysing the global coauthoring network of Ebola virus research, it was found that among the top 10 corresponding authors, 6 are in the core of the coauthoring network and are active scientists participating in much cooperation and with higher influence. They are Feldmann (No. 1), Geisbert (No. 2), Rollin (No. 3), Jahrling (No. 5), Kawaoka (No. 6) and Ksiazek (No. 10). Close cooperation relationship is established between them, and they also have their own cooperation networks.

Among them, Feldmann H, who is employed in NIH USA, ranks No.1 with 124 published articles and the h-index of 34. After graduation with the doctoral degree in 1988, Feldmann worked in the Institute of Virology of the University of Marburg in Germany at first, and then was in charge of the special pathogen project of the National Microbiology Laboratory of the Public Health Agency of Canada from 1999 to 2008. Now he works in the NIAID of NIH of the USA. Feldmann is an expert in the management of high level (BSL-4) laboratory and a consultant of the WHO on the viral hemorrhagic fever and related pathogens. He is mainly engaged in the pathogenic mechanism, animal model, diagnosis, medicine and vaccine research of hemorrhagic fever (4).

Geisbert TW from the University of Texas in USA ranks No. 2 in the quantity of the published articles, and the total citation frequency and the h-index of his articles both ranks the first in the world. Geisbert graduated from the West Maryland College (now McDaniel College), and obtained a doctorate from the Uniformed Services University of the Health Sciences. Now Geisbert is a professor of the Department of Microbiology and Immunology, University of Texas, and his main research direction is to develop the Ebola vaccine by utilizing the recombinant vesicular stomatitis virus as the vaccine vector (5). The research projects that he is carrying out are as follows: modifying the vesicular stomatitis virus vector to improve its security and immunogenicity; identifying the antigen needed for the preparation of polyvalent vaccine; determining the roles of the cell and host immune response in the immune protection (6).

Ranked No. 6, Kawaoka Y (Yoshihiro Kawaoka) receives much attention for the successful synthesis of Ebola virus and the attenuated Ebola virus. Yoshihiro Kawaoka, a Japanese American, is a virology professor at the University of Wisconsin-Madison. He once worked in the Institute of Medicine, University of Tokyo, and learned from Professor Robert (a globally recognized author-

Tab. 3. Top 10 Authors of the World with the largest quantity of articles on Ebola virus research.

\begin{tabular}{|c|c|c|c|c|c|}
\hline Author & Affiliation & $\begin{array}{l}\text { Quantity of Published } \\
\text { Articles }\end{array}$ & $\begin{array}{l}\text { Total Citation } \\
\text { Frequency }\end{array}$ & $\begin{array}{l}\text { Average Citation } \\
\text { Frequency }\end{array}$ & h-index \\
\hline Feldmann H & $\begin{array}{l}\text { National Institute of Allergy and Infectious Diseases } \\
\text { of National Institutes of Health, the USA }\end{array}$ & 124 & 3468 & 27.74 & 34 \\
\hline Geisbert TW & University of Texas, the USA & 71 & 3888 & 54.76 & 36 \\
\hline Rollin PE & Centers for Disease Control and Prevention, the USA & 66 & 3381 & 51.23 & 33 \\
\hline Becker S & University of Marburg, Germany & 65 & 2047 & 31.02 & 26 \\
\hline Jahrling PB & National Institute of Allergy and Infectious Diseases & 63 & 3232 & 59.85 & 32 \\
\hline Kawaoka Y & University of Wisconsin, the USA (2014) & 59 & 2333 & 39.54 & 25 \\
\hline Bavari S & $\begin{array}{l}\text { US Army Medical Research Institute of Infectious } \\
\text { Diseases (USAMRIID) }\end{array}$ & 59 & 1819 & 30.32 & 23 \\
\hline Hensley LE & $\begin{array}{l}\text { US Army Medical Research Institute of Infectious } \\
\text { Diseases (USAMRIID) }\end{array}$ & 58 & 2290 & 44.90 & 25 \\
\hline Nichol ST & Centers for Disease Control and Prevention, the USA & 51 & 2418 & 48.36 & 27 \\
\hline Ksiazek TG & University of Texas, the USA & 46 & 2039 & 46.34 & 26 \\
\hline
\end{tabular}




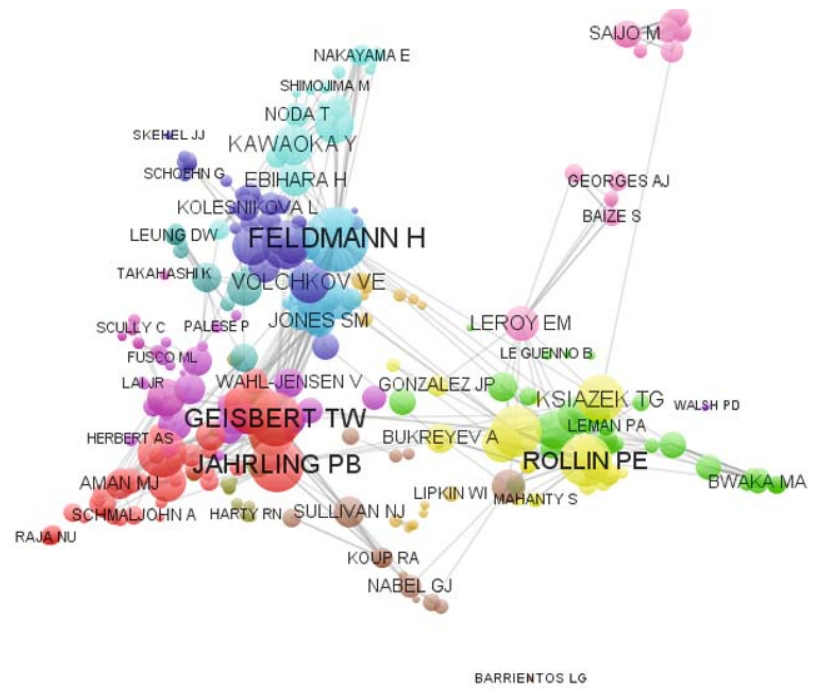

Fig. 3. Global coauthoring network of the Ebola virus research.

ity in the avian influenza research) of St. Jude Children's Research Hospital in the USA. Using the technology of synthesis of influenza virus, Yoshihiro Kawaoka and his team transferred the genes with which the Ebola virus produces RNA and protein into the cells for test, and then the artificial viruses could be formed on the cell surface. The appearance and structure of this artificial Ebola virus was quite similar to the natural Ebola virus, but its virulence was much weaker. So it can be used to study the interference and virulence mechanisms of Ebola virus or to develop the Ebola vaccine (7). His research articles are valuable for either controlling biological risk or developing vaccine (Fig. 3).

\section{Analysis of the highly cited articles on Ebola virus research}

The academic influence of articles can be reflected by the citation frequency. The more frequently an article is cited, the greater the influence of this article in the related field is. Most of such articles reveal a great discovery or provide important experimental data in some research field. Table 4 shows the 10 articles on Ebola virus research included in SCI which are cited most frequently, wherein 8 articles come from the USA, and 2 come from Gabon and Spain, respectively. All these 10 highly cited articles are completed cooperatively by two or more institutions.

In terms of the research content, 7 of the 10 highly cited articles mainly involve the structure and nosogenesis of the Ebola virus, 2 involve the animal experiment for Ebola vaccine, and 1 involves the host of Ebola virus. Among them, the article cited most frequently was published in 2001, which has been cited for 434 times in total, with the annual average citation frequency of 31. This article focused on the function of small molecule peptides encoded by the Ebola virus in accelerating the transfer of the virus, which was published collaboratively by Aaron Diamond AIDS Research Center and Rockefeller University (8). The article with the second highest citation frequency was published in 2000, which has been cited for 378 times in total, with the annual average citation frequency of 25.2. This article studied the effect

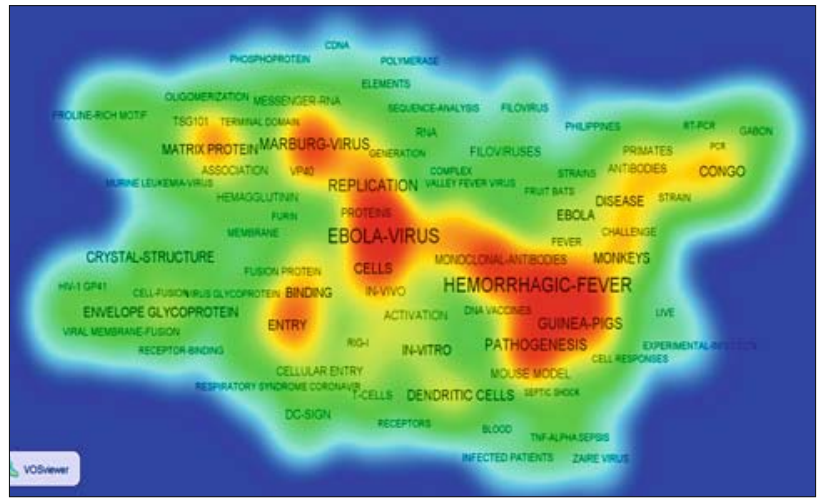

Fig. 4. Hot Keywords of the global Ebola virus research.

of Ebola vaccine on the primates via experiments and was published collaboratively by NIH and Centers for Disease Control and Prevention (9) (Tab. 4).

Analysis of the hotspots and the topic evolvement in the field of Ebola virus research

Hotspot analysis

Cluster analysis is performed on the main keywords in the field of Ebola virus research (Fig. 4). It is indicated that the current researche of Ebola virus mainly focuses on coat glycoprotein, monoclonal antibody, retrovirus, DNA vaccine, fusion protein, matrix protein vp40, matrix protein vp35, phosphoprotein, nucleoprotein, nucleocapsid protein and crystal structure of the Ebola virus. In addition, a few articles discuss the risk brought by Ebola virus as a biological weapon and its threat to organisms (Fig. 4).

\section{Analysis of topic evolvement}

The milestone articles (the bigger circle indicates a higher citation frequency) in the field of Ebola virus research are summarized, and the hotspot evolvement process in the field from 1995 to 2014 is analyzed through the sequence diagram of highly cited articles (Fig. 5) (the relevant articles published before 1995 are not included in the SCI database). It can be seen from the diagram that the Ebola virus research is divided into two phases.

Phase 1: basic research phase (1995-1998). The first highly cited article published in 1995 is an experimental study regarding the isolation and identification of new Ebola virus strains. From 1995 to 1998, the highly cited articles in the field of the Ebola virus research mainly focused on the viral glycoprotein, including the studies of mRNA, encoding and function of glycoprotein, and the mechanism of action of secreted glycoprotein and transmembrane glycoprotein in cells. In addition, along with the heated debate on the possibility of airborne transmission of the Ebola virus in the scientific community, the research articles on this topic published in this period also become highly cited articles.

It should be noted that the US Army Medical Research Institute of Infectious Diseases (USAMRIID) started the research on the airborne transmission of Ebola virus in 1992, and they believed that the Ebola virus can spread through the air among the non-human primates (including Macaca mulatta, Cercopithecus aethiops and 
Tab. 4. List of the highly cited articles in the field of Ebola virus research.

\begin{tabular}{|c|c|c|c|c|c|c|}
\hline Rank & Title & Author & Journal & $\begin{array}{l}\text { Publishing } \\
\text { Time }\end{array}$ & $\begin{array}{l}\text { Citation } \\
\text { frequency }\end{array}$ & Country \\
\hline 1 & $\begin{array}{l}\text { HIV-I and Ebola virus encode small } \\
\text { peptide motifs that recruit Tsg } 101 \text { to } \\
\text { sites of particle assembly to facilitate } \\
\text { egress }\end{array}$ & $\begin{array}{l}\text { Martin-Serrano, J; Zang, T; } \\
\text { Bieniasz, PD }\end{array}$ & NATURE MEDICINE & 2001 & 432 & The USA \\
\hline 2 & $\begin{array}{l}\text { Development of a preventive vaccine } \\
\text { for Ebola virus infection in primates }\end{array}$ & $\begin{array}{l}\text { Sullivan, NJ; Sanchez, A; } \\
\text { Rollin, PE et al. }\end{array}$ & NATURE & 2000 & 376 & The USA \\
\hline 3 & Fruit bats as researvoirs of Ebola virus & $\begin{array}{l}\text { Leroy, EM; kumulungui, B; } \\
\text { Pourrut, P }\end{array}$ & NATURE & 2005 & 324 & Gabon \\
\hline 4 & $\begin{array}{l}\text { C-type lectins DC-SIGN and L-SIGN } \\
\text { mediate cellular entry by Ebola virus } \\
\text { in cis and in trans }\end{array}$ & $\begin{array}{l}\text { Alvarez, CP; Lasala, F; Car- } \\
\text { rillo, J }\end{array}$ & JOURNAL OF VIROLOGY & 2002 & 288 & Spain \\
\hline 5 & $\begin{array}{l}\text { Endosomal proteolysis of the Ebola } \\
\text { virus glycoprotein is necessary for } \\
\text { infection }\end{array}$ & $\begin{array}{l}\text { Chandran, K; Sullivan, NJ; } \\
\text { Felbor, U et al. }\end{array}$ & SCIENCE & 2005 & 276 & The USA \\
\hline 6 & $\begin{array}{l}\text { A system for functional analysis of } \\
\text { Ebola virus glycoprotein }\end{array}$ & $\begin{array}{l}\text { Takada, A; Robison, C; } \\
\text { Goto, H et al. }\end{array}$ & $\begin{array}{l}\text { PROCEEDINGS OF THE NATION- } \\
\text { ALACADEMY OF SCIENCES OF } \\
\text { THE UNITED STATES OF } \\
\text { AMERICA }\end{array}$ & 1997 & 266 & The USA \\
\hline 7 & $\begin{array}{l}\text { Crystal structure of the Ebola virus } \\
\text { membrane fusion subunit, GP2, from } \\
\text { the envelope glycoprotein ectodomain }\end{array}$ & $\begin{array}{l}\text { Weissenhorn, W; Carfi, A; } \\
\text { Lee, KH et al. }\end{array}$ & MOLECULAR CELL & 1998 & 261 & The USA \\
\hline 8 & $\begin{array}{l}\text { Lipid raft microdomains: A gateway } \\
\text { for compartmentalized trafficking of } \\
\text { Ebola and Marburg viruses }\end{array}$ & $\begin{array}{l}\text { Bavari, S; Bosio, CM; Wie- } \\
\text { gand, E; }\end{array}$ & $\begin{array}{l}\text { JOURNAL OF EXPERIMENTAL } \\
\text { MEDICINE }\end{array}$ & 2002 & 251 & The USA \\
\hline 9 & $\begin{array}{l}\text { The virion glycoproteins of Ebola } \\
\text { viruses are encoded in two reading } \\
\text { frames and are expressed through } \\
\text { transcriptional editing }\end{array}$ & $\begin{array}{l}\text { Sanchez, A; Trappier, SG; } \\
\text { Mahy, BWJ }\end{array}$ & $\begin{array}{l}\text { PROCEEDINGS OF THE NATION- } \\
\text { ALACADEMY OF SCIENCES OF } \\
\text { THE UNITED STATES OF } \\
\text { AMERICA }\end{array}$ & 1996 & 248 & The USA \\
\hline 10 & $\begin{array}{l}\text { Accelerated vaccination for Ebola vi- } \\
\text { rus haemorrhagic fever in non-human } \\
\text { primates }\end{array}$ & $\begin{array}{l}\text { Sullivan, NJ; Geisbert, TW; } \\
\text { Geisbert, JB }\end{array}$ & NATURE & 2003 & 244 & The USA \\
\hline
\end{tabular}

Macaca fascicularis) $(10,11)$. The articles from the University of Manitoba, Canada, show a similar research result (12). Although the conclusions above goe against the current mainstream view that Ebola virus cannot spread through the air and needs further research to verify, it is still worth special attention.

Phase II, a transition phase from basic research to prevention and treatment research (1999-2011). Since 1999, the highly cited articles involve the humoral immune response and the intravascular cell apoptosis related to Ebola virus infection. From 2000 to
2008, the themes of the highly cited articles began to concentrate on testing method of Ebola virus and animal experiment of Ebola vaccine. Meanwhile, from 1999 to 2011, the structure and function of the glycoproteins of Ebola virus (e.g., vp35 and VP40) is still the research hotspot.

Distribution of the articles of Ebola virus research in major journals By analyzing the major journals which publish the articles regarding Ebola virus research, it is found that the Journal of Viro-

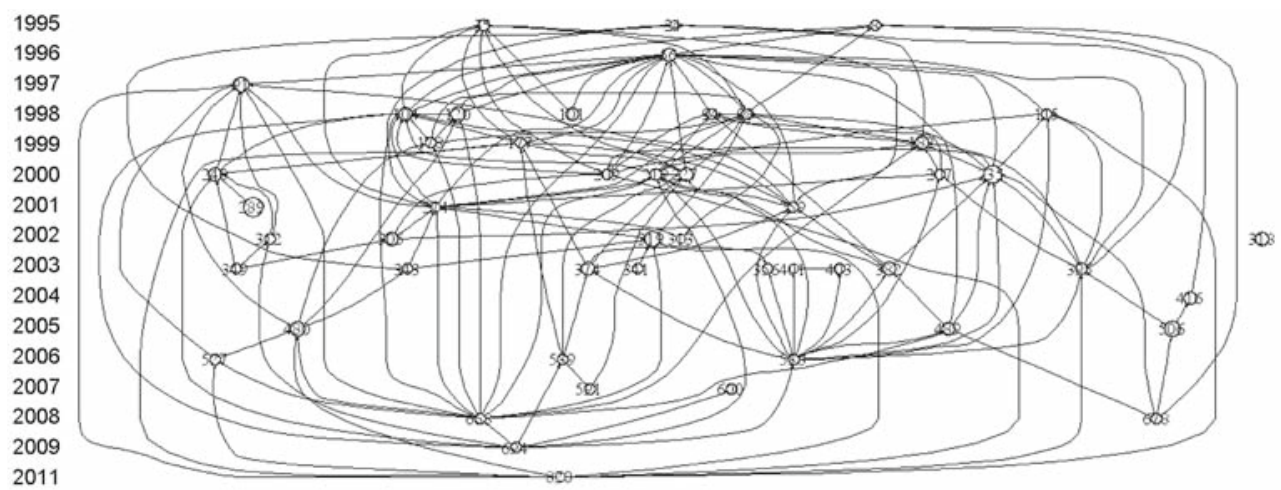

Fig. 5. Sequence diagram of 50 highly cited articles in the field of Ebola virus research. 
Tab.5. Top 10 major journals with the largest quantity of articles regarding Ebola virus research.

\begin{tabular}{lccc}
\hline Name of Journal & $\begin{array}{c}\text { Quantity of } \\
\text { Published } \\
\text { Articles }\end{array}$ & $\begin{array}{c}\text { Impact } \\
\text { Factor }\end{array}$ & Country \\
\hline Journal of Virology & 118 & 4.648 & The USA \\
\hline Journal of Infectious Disease & 107 & 5.778 & The USA \\
\hline British Medical Journal & 65 & 16.378 & The UK \\
\hline LANCET & 63 & 39.207 & The USA \\
\hline Science & 50 & 31.477 & The USA \\
\hline Virology & 46 & 3.278 & The USA \\
\hline Nature & 31 & 42.351 & The UK \\
\hline Journal of the American & 29 & 29.978 & The USA \\
\hline Medical Association & 25 & 3.434 & Netherlands \\
\hline Antiviral Research & 24 & 0.379 & The UK \\
\hline New Scientist & & &
\end{tabular}

logy ranks the first in the quantity of articles in this field, followed by Journal of Infectious Disease and British Medical Journal. In terms of the journal's impact factor, Nature ranks the first among the top 10 journals with the largest quantity of relevant articles. Among the top 10 journals, 6 are published in the USA, 3 in the UK, and 1 in Netherlands (Tab. 5).

\section{Subsidization for Ebola virus research}

Through analysing the major funding situation of the Ebola virus research worldwide, the projects subsidized by the NIH of the USA publish the largest number of articles. The other major funding agencies include the Defense Threat Reduction Agency of the USA, Canadian Institutes of Health Research, Public Health Agency of Canada, German Research Foundation, French National Research Agency, French Foundation for Medical Research, Japan Society for the Promotion of Science, German Schering Foundation and Boston University of the USA (Fig. 5).

\section{Conclusion and discussion}

Having an objective view on the results of literature analysis of the Ebola virus research

Literature metrology and visualization analysis can assess the current situation and trend of Ebola virus research from the view of literature, and intuitively reflect the national or regional distribution, core research institutions, important experts and research hotspots in this field (13). Considering that the Ebola virus is an important biological warfare agent, some researches may not be published to the public. So this study can only reflect the basic information of the research in this field. The conclusions are made based on the literature analysis, and can serve as a component of the overall situation of the Ebola virus research (14).

Paying close attention to the biosafety risk of Ebola virus research

Through the analysis on the hotspots of the Ebola virus research, it can be found that the potential biosafety risk of the Ebola virus research has been discussed by many scientists, and scientists from various countries have to be vigilant to this issue when carrying out such research. Therefore, it is necessary for us to follow closely the key research institutions abroad and the research trends of the scientists, and carry out the dual-purpose risk assessment timely so as to get ready for response to terrorist activities. Meanwhile, appropriate laboratory biosafety standards and code of conduct should be established based on the potential risk of the research performed in order to prevent the accidents threatening the biosafety.

\section{References}

1. Feldmann H, Geisbert TW. Ebola haemorrhagic fever. Lancet 2011; 377 (9768): 849-862.

\section{2. http://www.who.int/csr/don/2014_08_19_ebola/en/.}

3. zhangming-hua,leier-qing. Frontier and evolution of cognitive neuro science based on knowledge map analysis. Bull Acad Mil Med Sci 34 (1): 71-75.

4. http://www.niaid.nih.gov./labsandresources/labs/aboutlabs/lv/diseasemodeling/pages/default.aspx.accessed at 2014-12-12.

5. Geisbert TW, Bailey M, Hensley L. Recombinant Adenovirus Serotypes 26 and 35 Vaccine Vectors Bypass Immunity to Ad5 and Protect Nonhuman Primates Against Ebolavirus Challenge. J Virol 2011.

6. Geisbert TW, Lee AC, Robbins M et al. Postexposure protection of non-human primates against a lethal Ebola virus challenge with RNA interference: a proof-of-concept study. Lancet. 2010; 75 (9729): 1896-1905.

7. Yasuda J, Nakao M, Kawaoka Y. Nedd4 Regulates Egress Of Ebola Virus-Like Particles From Host Cells. J Virol 2003; 77 (18): 9987-9992.

8. Martin-Serrano J, Zang T, Bieniasz PD. HIV-I and Ebola virus encode small peptide motifs that recruit Tsg101 to sites of particle assembly to facilitate egress. Nature Med 2001; 7 (12): 1313-1319.

9. Sullivan NJ, Sanchez A, Rollin PE. Development of a preventive vaccine for Ebola virus infection in primates. Nature 2000; 408 (6812): 605-609.

10. Jaax NK, Davis KJ, Geisbert TJ. Letal Experimental Infection Of Rhesus Monkeys With Ebola-Zaire (Mayinga) Virus By The Oral And Conjunctival Route of Exposure. Arch Pathol Lab Med 1996; 120 (2): 140-155.

11. Reed DS, Lackemeyer MG. Aerosol Exposure To Zaire Ebolavirus In Three Nonhuman Primate Species: Differences In Disease Course And Clinical Pathology. Usamicrobes Infection 2011; (13): 930-936.

12. Kobinger GP, Leung A, Neufeld J. Replication, Pathogenicity, Shedding, and Transmission of Zaire ebolavirus in Pigs. JID 2011; 204 (15): 200-208.

13. Nadvornik P, Cierny G, Bernadic M. The future of spinal cord stereotaxy. Bratisl Med J 2013; 114 (5): 295-297.

14. Jong-Hyuck K, Wi-Young S. Association of smoking frequency and cigarette consumption with obesity in Korean adolescents. Bratisl Med J 2012; 113 (10): 599-603.

Received February 6, 2015. Accepted March 6, 2015. 